\title{
Reply to re unexpected amaurosis occurring after peribulbar anesthesia: Exploring the causes in two cases
}

\author{
Amina Rezkallah ${ }^{1}$ iD, Nezar Gargori ${ }^{2}$, Philippe Denis ${ }^{1}$, \\ Véronique Waldmann', Thibaud Mathis ${ }^{1,3}$ \\ and Laurent Kodjikian ${ }^{1,3}$ iD
}

Dear Editor,

We thank Pelligrini et al. for their interest regarding our recent article entitled "Unexpected amaurosis occurring after peribulbar anesthesia: Exploring the causes in two cases."1 The authors reported four cases of amaurosis after peribulbar anesthesia (PB). They proposed an alternative mechanism to this momentary amaurosis: the increase of intraorbital pressure. They think that this increase can damage the axoplasmic flow of the optic nerve, the blood supply to retina or optic nerve. However, they have never noticed any kind of amaurosis using hyaluronidase. Hence, they suggested to use hyaluronidase enzyme to avoid the abrupt increase of intraorbital pressure, by facilitating the anesthetic spreading into the orbit. In support of this hypothesis, they added that for three of their cases, the visual acuity recovered after a decompression surgery was performed in order to reduce the intraorbital pressure. But one can assume that the vision would have recovered even without the decompression surgery just as for our cases and one of their cases.

Hyaluronidase is a mucolytic enzyme derived from mammalian tissue or synthesized in vitro in pure form using recombinant technology and it reduces the obstacle that the interstitial matrix presents to fluid and drug transfer. ${ }^{2}$ Hyaluronidase permits to decrease the volume of anesthetics used. However, In France, hyaluronidase is neither longer used nor authorized for PB. This enzyme preparation is extracted from animals' testicles or ovary cells. Although extraction has been reported free of Bovine Spongiform Encephalopathy, ${ }^{3}$ the prion remains an undetectable protein particle. The risk of Creutzfeldt-Jakob disease is rare but real. ${ }^{4}$

For this reason, we cannot confirm or contradict the hypothesis of Pelligrini et al. because we used ropivacaine and clonidine for our two cases and for almost all the PB. Moreover, we only have two cases of amaurosis, among all our 3000 PB per year, even when the block is performed in patients with advanced glaucoma and very elevated ocular hypertension before filtering surgery. To the best of our knowledge, there is no evidence in the literature that this transient elevation of intraorbital pressure, regulated by the compression following the block, can damage the axoplasmic flow of the optic nerve or the blood supply to retina or optic nerve inducing an amaurosis.

\section{Declaration of conflicting interests}

The author(s) declared no potential conflicts of interest with respect to the research, authorship, and/or publication of this article.

\section{Funding}

The author(s) received no financial support for the research, authorship, and/or publication of this article.

\section{ORCID iDs}

Amina Rezkallah (iD https://orcid.org/0000-0001-6110-2113

Thibaud Mathis (iD https://orcid.org/0000-0002-1418-1872

Laurent Kodjikian iD https://orcid.org/0000-0002-3908-6716

\section{References}

1. Rezkallah A, Gargori N, Denis P, et al. Unexpected amaurosis occurring after peribulbar anesthesia: exploring the causes in two cases. Eur J Ophthalmol. Epub ahead of print 24 December 2020. DOI: 10.1177/1120672120984399.

2. Dunn AL, Heavner JE, Racz G, et al. Hyaluronidase: a review of approved formulations, indications and off-label use in chronic pain management. Expert Opin Biol Ther 2010; 10: 127-131.

3. Rzany B, Becker-Wegerich P, Bachmann F, et al. Hyaluronidase in the correction of hyaluronic acid-based fillers: a review and a recommendation for use. J Cosmet Dermatol 2009; 8: 317-323.

4. Pustiglione M, Torres RAT and Sa EC. Doenças causadas por príons e provável nexo ocupacional. Rev Bras Med Trab 2014; 12: 96-99.

\footnotetext{
'Department of Ophthalmology, Croix-Rousse University Hospital, Hospices Civils de Lyon, University of Lyon I, Lyon, France 2Department of Anesthesiology, Croix-Rousse University Hospital, Hospices Civils de Lyon, University of Lyon, Lyon, France ${ }^{3}$ UMR-CNRS 5510 Matéis, University of Medicine Lyon I, Lyon, France

Corresponding author:

Laurent Kodjikian, Department of Ophthalmology, Croix-Rousse University Hospital, 103, Grande Rue de la Croix-Rousse, Lyon, Cedex 04 69317, France.

Email: laurent.kodjikian@chu-lyon.fr
} 